\title{
How to Make Thin Journalism Strong?
}

\author{
Experiences of a Public Journalism Project in Finland
}

\author{
HeIKKI HeIKKILÄ
}

The concepts of audience and public create an interesting division within media studies. On the one hand, the empirical research on readers and viewers talk primarily about 'the audience'; if any mention is made of 'the public', it will usually be used interchangeably with 'the audience' . Thus, if the distinction between the audience and the public should be analytically meaningful, as some scholars insist (see Dahlgren 1995, 19), then audience studies seem to have refused to take it seriously. On the other hand, for scholars who take an interest in the media and democracy, this distinction is of great importance. Even if they seem to have an analytical advantage over audience researchers, it is not quite clear what this distinction means empirically. Is the public anything else but a slogan?

This article explores the empirical meanings of the public through a case study. It is inspired, firstly, by the theory and practices of public journalism (see Rosen 1999; Glasser ed. 1999). Secondly, it echoes a more general interest that has been re-emerging in Finland (among other places) in the concept of the public. Some scholars have gone so far as coining a brand new word (julkiso) into Finnish language to denote the public in contrast to the audience (yleisö), because hitherto the word yleisö has covered in addition to the meaning of the audience also that of the public (Pietilä \& Ridell 1997, 95). Later this initiative has been elaborated both theoretically and empirically. ${ }^{2}$

\section{Thin and Strong Journalism}

One of the foremost proponents for conceiving 'the public' is James Carey, whose recurring strategy is to draw useful parallels between 'journalism as we know it' and its often unparallel past (Carey 1997, 331). ${ }^{3}$ In this vein he suggests that in the advent of the United States, there existed an almost organic relationship between the newspaper and its readers (Carey 1987, 10). The primary subjects of the news in those days were the readers - a highly exclusive group of males with property - who had a vested interest in the news. They also gathered to discuss the news critically and rationally. The readers of the news were critical in the sense that nothing in the public sphere was taken for granted. They were rational in the sense that each speaker was expected to state his reasons for believing in any given assertion; there was no intrinsic appeal to status or tradition for authority (ibid. 10). 
Since the late $18^{\text {th }}$ century and the early $19^{\text {th }}$ century the volume and the scope of public communication as well as the contexts of reception have dramatically changed and expanded and at the same time been democratised. While Carey's description obviously does not speak of today's circumstances, its critical strengths have in fact increased. News journalism today is not grounded in the public in the meaning illustrated above, but in the representative logic of society. The readers are now only distantly the subjects or stakeholders in the news. It is far more common for ordinary people to be spoken about in the news than for ordinary people to speak for themselves in the news (Murdock 1992, 31; see also Ekecrantz \& Olsson 1990). Furthermore, as many reception analysts suggest, the news barely generate rational and critical discussion among readers or viewers (Jensen 1990; Ridell 1998). From this perspective news practices that commonsensically appear so functional for democracy, begin to seem disturbingly unfunctional, if not dysfunctional.

If we take it that the unrepresentativeness of news actors and the absence of discussion about the news are interrelated problems, the following argument becomes justified: News journalism that takes action only once topics have been identified, agendas set, and options delineated, is 'thin' in terms of its democratic performance (see Barber 1984, 157). ${ }^{4}$ There is much to be said for 'thin journalism'. It is congruent with our constitutions and liberal convictions. It is in line with the logic of modern societies in general. And in spite of occasional criticisms, its legitimacy has never been seriously threatened. Ultimately thin journalism seems to provide journalists, newsrooms, and media corporations with what they need so that they can go about their daily work efficiently and economically (see Gans 1980; McManus 1994). If newspeople were to give up their routines based on the representative logic, this would place them at serious risk.

The problem with thin journalism is that it claims no active role for journalism in the quality of public discussion. It does little to improve the conditions for citizens' active participation in its own realm. In order to become 'strong' - following Barber's distinction - journalism needs to develop practices that are more closely aligned with the features of the public. It should address readers and viewers as stakeholders with vested interests, and promote their rational and critical discussion about the subjects of news as well as the performance of news journalism.

The idea of strong journalism is first of all a way of criticising contemporary news practices. On the other hand, the best way to transform critique into constructive suggestions is to set out alternative practices and to see where they might lead. Perhaps the most impressive attempts to experiment with more participatory practices have been made by journalists in the United States under the banner of public or civic journalism.

The debate about public journalism is rich with eloquent or witty descriptions that either endorse or deride its ideas. In the absence of fixed definitions, the best description I have come across argues that public journalism sets itself the task of promoting and improving the quality of public life, rather than just reporting on or complaining about it (Glasser \& Craft 1996, 153). In doing so public journalists pay particular attention to citizens' everyday lives and treat their experiences as a source of valid information or knowledge. This information is often derived from discussion groups that are seen as resources for the newsroom. In exchange, journalists set themselves to public resources for citizens by making those in power accountable to their questions, by seeking social groups or individuals who have a stake in a perceived issue, and by providing them with a public role in the news. ${ }^{5}$ Instead of antagonism, public journalism attempts to enhance dialogue between citizens and institutions; dialogue that takes social prob- 
lems seriously and does not escape conflicts of interests but aims at resolving the common problems.

By 1997 the ideas of public journalism had inspired more than 300 projects in the US (Friedland et al. 1998, 191). Two years later, the number in Finland was no more than two. Aamulehti, one of the biggest dailies in the country, launched some smallscale experiments in 1997 that included a project called 'budget jury', in which 12 residents of the city of Tampere (where the newspaper is published) were recruited to a series of discussions on the forthcoming city budget. The impact of the budget jury and other experiments have been latent, but by no means insignificant (see Kunelius 1999a, 1999b).

In what follows I shall examine the projects and new practices developed at Savon Sanomat (a daily published in Kuopio in eastern Finland) since autumn 1998 by applying the analytical tools derived from Carey. Analytically, the public is assumed to consist of persons with vested interests, who are capable of discussing the news rationally and critically. The analysis describes the project in some detail, for three reasons. Firstly, it follows from the experimental framework that the insights are deeply absorbed in practical situations, which means that the inquiry has to proceed accordingly. Secondly, I assume that the contemporary practical problems relating to citizens' discussions in Finland at the turn of millennium should be relevant or at least intelligible to contexts that resemble our circumstances. Thirdly, whether I like it or not, this article will be read as $a$ public journalism project. For those who wish to evaluate the idea respective to this case, it is only fair to be as specific as possible. For all these reasons the analysis has to start with a description of the local immediate context that made the experiments possible.

\section{Setting the Scene}

In a way, the foundations for the public journalism projects at Savon Sanomat were laid as early as spring 1997. At that time 16 journalists at the paper (about one-fifth of the staff) were interviewed to find out about their ideas on news journalism, the paper's performance, and the current ideological and economic challenges to what they regarded as 'good journalism'. The main tone in the interviews was critical. Apart from the normal frictions that you will see in any institution or workplace, everyone (bar one veteran interviewee) seemed to be confused about the state of journalism and themselves practising it. The following two passages capture some critical and self-reflexive moments from the interviews:

Suppose we decide [in the newsroom] that let's write a story on unemployment. Unemployment, of course, should concern an awful lot of families. So, [the question is asked at a news meeting,] "does anyone here know someone who is unemployed?" "Oh, yeah! I guess there's one who lives in my block of flats." (sarcastically). This is what it's like, you know! (female journalist no. 6).

I've been giving a lot of thought to these long-term trends. How are we supposed to cover them, bearing in mind that they're not "news" in a conventional sense? Lots of things that happen in people's lives remains obscure to us. [This explains] why it's so difficult to cover unemployment. If people are out of work for years it's no longer news to us. Still, it would be good to keep writing about it, even if these 
people don't fit into the readership profile (makes "air quotes" in an ironic fashion) that the marketing section talks about. (female journalist no. 10).

This line of criticism ${ }^{6}$ finds serious flaws in contemporary journalistic practices. It suggests that news journalism has lost its touch with the reality of everyday life and that journalists are deprived of contacts with people presumably below their social rank. Whereas the first passage above points to journalists as persons, the latter locates the problem in news practices, news values, and also in marketing values. These critiques are also central to the tenets of public journalism (see Rosen 1996; Merritt 1995). Even though this criticism stems directly from journalists' own experiences, it was enough to convince some newsroom executives that it might be worthwhile for them to experiment with public journalism. However, it took more than one year for the projects to get started.

Finally, between autumn 1998 and spring 1999, the paper conducted three smallscale projects involving six journalists, a researcher, and an informal support group within the newsroom. Overall responsibility, however, rested with one single reporter, who took care of most practical arrangements and briefings, who wrote most of the stories, and coordinated the efforts to develop subsequent work at the newsroom. Given the scarcity of resources, it is clear that these projects are entirely different from those carried out in the US. ${ }^{7}$

All projects were based on a similar method and assignment. The reporters gathered six groups of ordinary citizens who where invited to discuss their concerns, to frame problems, raise questions, and find solutions. The idea was to have these groups contributing to the newswork, while the reporters would commit themselves to developing public discussion on the basis of these contributions. In a way, this relationship is not entirely different from the symbiosis that journalists usually create with institutions. The discussion groups were assumed to have information that news journalism needs, while journalists controlled the means of publicness that the participants were allowed to use. The fact that the journalists' partners in this symbiotic relationship were 'ordinary citizens' and not politicians or experts, changed the meanings of this symbiosis in many ways. It did not mean, however, that journalists would give up their judgement about the forms and content of the stories.

The participants were selected using the 'snowball technique', a common method in qualitative research (Schröder 1999, 46). First, a group of reporters sat down to set up an advisors' list consisting of persons who were neither journalists' friends nor established news sources. Once the advisors had been informed of the projects by phone, they were asked to suggest two or three names they would like to see in a group. This round of phone calls produced a list of more than 150 candidates, of which about 50 were invited. Eventually 46 of them took part in the discussions.

The first project, (which was called 'Citizens!'), focused on generational differences in Kuopio, the paper's home town. The participants were divided into three groups, i.e. senior citizens born in the 1930s, those born in the 1950s, and younger adults born in the 1970s. Each group met twice to collect a total of 7-8 hours of intensive talk. In the first session the groups focused on problems, in the second they tried to find solutions to the problems they had detected. During the project the groups became so interested in each other's viewpoints that a third meeting was held in which some members of all groups were present. This extra session was more informal, but it was also covered in the paper. 
The second project was launched a couple of months later in two small municipalities, where 'community groups' met on three occasions. In the first two sessions the groups reflected upon their concerns and the extent to which residents could influence local decision-making. In the third meeting the groups had the opportunity to present their questions and suggestions directly to the local authorities. The third project (called 'Voters') was an ad hoc experiment in which a group of citizens spent an evening discussing topics they thought would be relevant in the parliamentary elections; the following evening they were allowed to 'interrogate' local political candidates. Since this project the paper has decided to convene the group once a year to meet the MPs elected from their constituency.

All these group meetings and discussions took place in the presence of two reporters and the researcher, who also acted as a moderator. The discussions resulted in a dozen stories, which were expected to lead to 'spin-off stories' and transform into public processes or even 'beats' that would be under constant supervision in the newsroom. The projects were open-ended, but as it turned out they remained rather short-lived. Spin-off stories that were supposed to develop public discussion further and cater it with journalistic tools available remained quite sporadic, and after May 1999 they ceased altogether. In autumn 1999, however, the paper took a step towards institutionalising a similar approach by establishing a weekly section to cover local issues from the residents' perspective. The reporter responsible for the projects is also in charge of this new section. As far as I am aware this section is the first attempt to practise public journalism on a regular basis in Scandinavia.

\section{Vested Interests: Pleasure and Relevance}

The assignment in the projects sounds plain and simple: the reporters were supposed to write stories about situations in which ordinary citizens meet to talk about contemporary problems. However, this task was heavily loaded with theoretical presumptions: why problems, why ordinary citizens, why discussions?

Firstly, the inspiration was drawn from Dewey's (1991, 12 [1927]) idea about the public: for Dewey, the public begins to emerge when indirect consequences of human actions - i.e. problems - are recognised and there appears an effort to regulate them. Thus, the projects aimed at detecting problems that would deserve public attention. Secondly, still following Dewey, average citizens were treated as experts of everyday life whose insights and perspectives would likely differ from the way how institutions see the world. No-one had prior knowledge about what these perspectives would be like. Thirdly, a lot of time and expectations was placed on discussion because it was assumed that lengthy deliberation would serve as a method 'to know good in common that we cannot know alone' (Sandel 1998, 183). Or, in Dewey's (1991, 219) rather obscure words: "There is no limit to the liberal expansion and confirmation of limited personal intellectual endowment, which may proceed from the flow of social intelligence when that circulates by word of mouth from one to another in the communications of local community."

One way to start with our analysis is to look at whether the participants became involved in the discussions and how they began to see their stakes or vested interests in the topics they talked about. This analysis is based on the dynamics of the discussions on the one hand, and on the participants' written evaluations about the projects, on the other. ${ }^{8}$ We can then move on to see what happened when the discussions were trans- 
formed into news stories and what problems this process caused for the news organisation.

The first thing that comes out of the participants' evaluations is pleasure: they clearly appreciated the opportunity to 'get serious' and learn from one another's experiences and their sometimes very different viewpoints. Most of the participants would probably agree with a female participant of Citizens!, who wrote that she had not enjoyed anything as much as this for ages. ${ }^{9}$ In contrast to what vulgar elite theorists might assume, the participants found the lengthy and sometimes 'untidy' discussions about local decision-making or values in society highly entertaining, even though these subjects hardly match the standard definition of fun. What is even more significant is that a major source of enjoyment was the public character of these discussions. Some participants said quite frankly that they were happy to see themselves in the paper, while others underlined that the projects gave them an exceptional opportunity to influence public opinion or decision-making. Without the presence of journalists and the prestige of the paper, the discussions would have had a minor significance for the participants.

The pleasure of public talk reveals a somewhat republican undertone, which is at odds with conventional wisdom about how citizens are supposed to relate to the news and politics. However, this participatory impulse would be short-lived unless the participants perceived the discussions as relevant. Two aspects became indispensable for the groups in maintaining their public happiness. Firstly, the issues raised had to be familiar and recognised at the level of everyday life: unless the problems 'rang true', their relevance would be questionable. Secondly, the problems should entail at least a vague possibility of action. If the problems related to circumstances that were beyond human powers, they would probably have less relevance. On the other hand, even a certain amount of existentialist anxiety shared with others was found liberating and thus relevant by the participants.

In their search for relevance the groups took different routes. Some of them were able quite easily to name the problems at the top of their agenda and weave the participants' concerns together. The clearest example of this was the identification in the senior citizens' group of common ground in problems related to insecurity. Having shared their testimonies, the participants were convinced that insecurity restricts their lives in a very concrete way, and that cannot be explained away by statistics or probability calculations. It was much harder to define the causes of insecurity and to find solutions. Some participants were more inclined to see this as a question of law and order, while others preferred to discuss the problems in a broader social context. These different approaches complicated the discussion, but this seemed to motivate the group to try even harder to make sense of the problem.

In other groups, too, the relevance seemed to increase, when the problems became redefined or altered. As a consequence even practical problems like housing or transportation, keenly discussed among the young adults, were framed as questions of power. This would seem to suggest that relevance stems from questions that are not normally asked. This was also true in Voters, who insisted that abstract values have relevance in society because in their view politicians tend to avoid expressing them in explicit terms.

Two community groups had more difficulties in their search for relevance. Quite surprisingly, participants in the peripheral and declining small town of Suonenjoki found it hard to identify local problems that would directly affect their lives. Instead, the group chose to envision new practices for local democracy and decision-making. In the young, heterogeneous, and prosperous Siilinjärvi, relevance became an openly contested issue. Half of the group wanted to direct public attention to the life situations of 
mental care patients, many of whom had been de-institutionalised in the municipality during the 1990s. The other half failed to see the relevance of this topic, because they claimed they had not personally witnessed the problem. What made the discussion even more difficult was the fact that the problem stemmed from government policy leading to a sharp reduction in the number of mental hospitals throughout the country. Therefore, some participants felt the chances of tackling the problem here and now were quite limited or even non-existent.

For the newspaper the discussions introduced a difficult challenge. While the participants were keenly involved and enthusiastic, it is a different matter altogether to convey that atmosphere to the readers and hopefully to get them to see their stake in the topics. In practical terms, only a fraction of a lengthy discussions would fit in a page or a story. In order not to lose anything essential the stories were usually arranged in the space of one page composed of three types of stories (see Image 1). First, all topics, problems, and solutions mentioned within a discussion were presented in a left sidebar. The list would give names to participants' concerns and provide a short description of their causes and effects as the groups defined them. Secondly, in order to introduce the participants to the readers, the reporter selected one quotation from each member; these were placed in a right sidebar. Thirdly, the reporter wrote 1-3 stories describing and condensing the substance and atmosphere of conversations from the perspective of a sympathetic observer.

In most cases the publication of the stories strengthened the participants' commitment to the subjects and viewpoints they had addressed. At the same time, however, they complained that the stories did not have the effect they had anticipated. The participants had been caught in face-to-face discussions about the stories in the streets and shops, but mass mediated reactions were very restrained. The number of spin-off stories produced by reporters and often the quality of these stories were also a disappointment for the participants. These experiences point at problems within the news organisation, but also at problems related to news genres.

Studies on public journalism projects in the US underline the longevity and patience that is required in attempts to address readers as stakeholders (Friedland et al. 1998, 203). While newspeople often lose their interest in a particular topic after giving it exhaustive coverage, it may take citizens months or even years to realise their stakes or vested interests. The main responsibility of keeping the discussion alive often falls to journalists, who are supposed to repeat relevant questions even if they would not result in answers and comments, and to frame old issues from new perspectives.

The fact that stories were usually appreciated by the participants, but there were not many signs that they had encouraged readers to act publicly, partly comes down to everyday reading practices. Even though the stories on the brainstorming sessions were edited and condensed, they were never going to capture the undivided attention of readers leafing through their papers over breakfast. In retrospect, it might have been wiser to split up the material into smaller stories and publish them sequentially. In addition, in the layout we should have paid more attention to patterns for feedback and comments. These lessons have been taken on board in the design of the latest local coverage section that includes direct question boxes, phone-in facilities, e-mail and URL addresses etc. (see image 2).

Question boxes and phone-in facilities are, of course, only partial solutions. The main challenge remains the same: how to write engaging and dialogical news stories. Although there may be no absolute solutions to this problem, this should not be allowed to invalidate the efforts, but rather push them forward. 
Image 1.

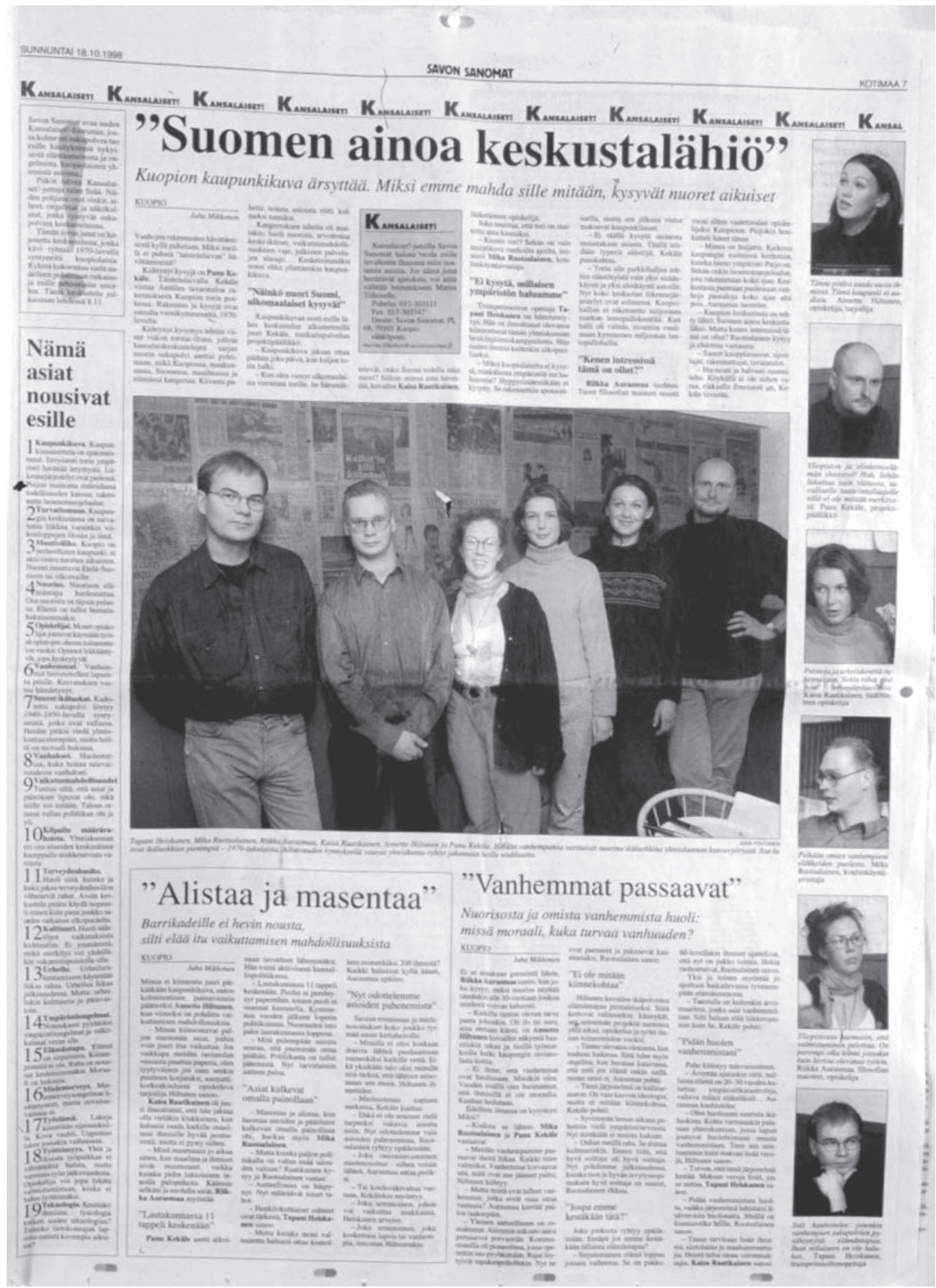


Image 2.

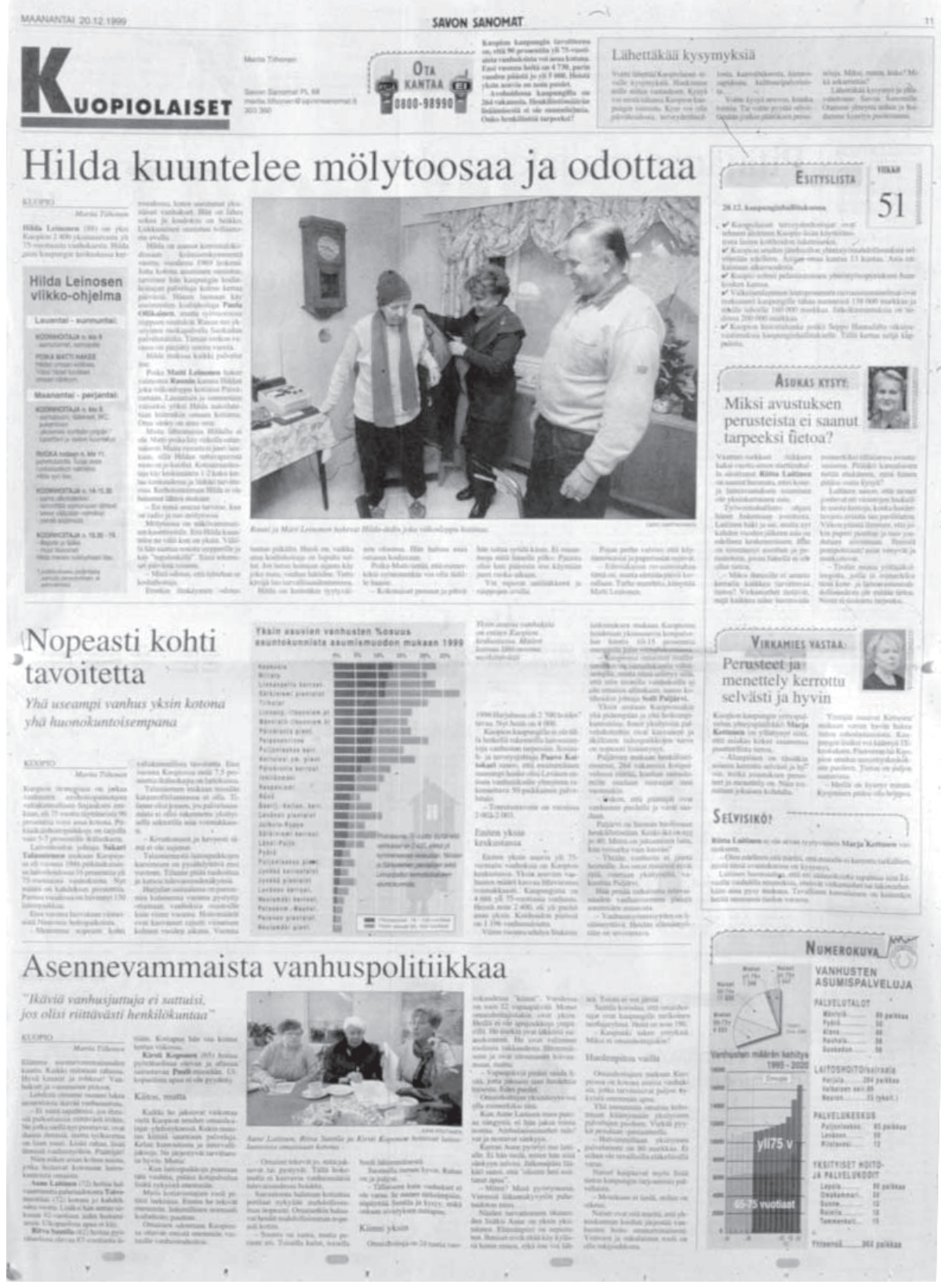

\section{Everyday Rationality: The Art of Connections}

The hermeneutic tradition, theories of participatory democracy, and communitarian philosophy all regard conversation as a value in itself. It is argued that in conversation, we learn to know something we could not know individually. For Barber $(1984,119)$, deliberation - a special form of discussion - leads to transformations that change the way participants conceive the world. Empirical work with citizens' deliberative discus- 
sion groups has shown that these deliberations are likely to produce something new. It is said that instead of slicing 'things' analytically into pieces as experts tend to do, deliberative groups tend to link issues together and seek for connections and coherence, which leads them to question things we would otherwise take for granted (see Harwood Group 1993; Huxman \& Iorio 1996). In this sense discussion groups may entail a specific form of rationality, which is the second aspect in Carey's description of the public.

In terms of their productivity alone, the project groups confirmed these assumptions. For instance, three Citizens! groups identified 15-20 major problems in their first sessions and were able to conceive even more solutions at their second meeting. Many of these initiatives questioned taken-for-granted truths without sounding unrealistic. For instance, the senior citizens suggested that one way of alleviating their sense of insecurity would be to bring back the janitor system in blocks of flats. They were well aware that janitors had been made redundant for reasons of saving costs. However, the group called into question the common assumption that janitors always cost more than the services of 'faceless companies'. And even if this were the case, the participants doubted whether residents really considered low service costs as more important and valuable than a sense of security. This is one of many examples of how the groups produced reasonable questions for public scrutiny that are unlikely to emerge from institutional sources.

Another 'new' question raised by Citizens! was in fact so old that it had disappeared from the public agenda at least ten years ago. The group of young adults even surprised themselves in taking such strong views about the architecture in the town centre. Kuopio is widely known in Finland for its market square, which is surrounded by a disturbing mixture of different architectural styles. On the one hand there are old historic buildings such as the Town Hall and the famous Market Hall, while the two other sides of the square are flanked by massive concrete department stores built in the 1970s and 1980s. One of these department stores is known, for instance, by the nickname 'Finnjet', once the biggest cruiser in the Baltic Sea - a clear statement about what people think of its aesthetic qualities.

Having shared their resentment at the townscape the group drew up a long list of ideas as to how the situation could be improved. It was suggested, for instance, that the owners of the buildings would be obliged to erect new facades to hide the grey concrete elements. In anticipation of the obvious counterargument that this was too expensive, they reminded that department stores regularly have facelifts indoors; so why couldn't they have this one facelift on the outside?

The middle-aged group in the Citizens! project provided an even more impressive example of conceiving new perspectives on contemporary problems. The issue at the top of their agenda was elder care. Their concerns reflected personal experiences among some participants of how their own parents had failed to receive adequate care and attention in health care institutions. The problem stemmed from the austerity budgets in the public sector. The group anticipated that the situation will be much worse by the time they themselves are old. They concluded that even if the problems were essentially about money, immediate action was needed at the local level.

The participants pinned their hopes on voluntary work and civic organisations in the third sector (see Rifkin 1995). The group saw in this a positive ideological change that would shift responsibilities from the welfare state to groups and individuals. Even those participants who worked in the public sector were in favour of this change.

The group dwelled for quite a long while on another problem that initially had nothing to do with elder care, the welfare state, or the third sector. The participants claimed 
that their generation took their work too seriously. They admitted that their attitude to work was almost passionate, but at the same time they had noticed that working conditions and the atmosphere in the workplace had changed for the worse during the economic recovery in the late 1990s. The group began to look for safe havens from the distress of work, and quite surprisingly turned to the option of voluntary action.

The art of connections entered the picture when the participants imposed the promises of the third sector on themselves. It appeared that the solutions of elder care could not be separated from the problems of the workplace. Ordinary citizens cannot assume responsibility for elder care unless actions are taken at the same time to relieve their pressures at work. Curiously enough, the group concluded that the effort to improve elder care should start from the job market. This question would effectively challenge the often hollow political or academic rhetoric that attack the welfare state either from a neoliberalist or communitarian framework.

The Voters project and the two community groups were somewhat less creative in their deliberations. In Voters the problems boiled down largely to lack of time. The participants complained that in their first discussion they only just got started, whereas in the second session the discussion was dominated quite self-righteously by the political candidates. In the community projects the groups had more time for deliberation than any other groups. Even so, their contributions remained less impressive than those of the Citizens! groups. This has probably nothing to do with the participants' competencies, but is due to local circumstances that seem to impose various restrictions on their imagination.

In both community groups local affairs - and especially those relating to local politics - seemed to be too distant from the participants' everyday lives. At first glance this may seem paradoxical, but upon closer inspection we can find quite obvious explanations. Firstly, there is nothing surprising about the assumption that citizens feel alienated from local administration. Research has shown that local participation tends to be rather passive and people think that local political power is excessively centralised (see Pekola-Sjöblom 1997; Borg 1998, 91). From this it follows that when the residents are allowed (or even compelled) to participate, they feel inadequately informed. Local politicians and civil servants, often make the situation worse by setting high informational standards for lay people who wish to participate. This was clearly evident in our projects when the groups were given the opportunity to meet local authorities. Independent of the discussions themselves, civil servants did not give very high marks for residents' knowledge or rate of interest. Nor did they think that the lack of active participation was a serious problem for local democracy (Heikkilä \& Kunelius 2000).

Secondly, the lack of creativity within the groups points at a lack of representativity within the projects. The assumption in the projects was that the groups cannot and need not be strictly representative. It appeared that all groups were slightly biased in one way or another, but it was only in the community groups that this caused real problems. It turned out, for instance, that among the participants there were no regular customers of health care services, social welfare services, or even children's day care. In both groups there was a strong overrepresentation of rather well-to-do, middle-aged residents. In addition, the group in Siilinjärvi turned out be rather polarised with regard to place of residence, which resulted in radically different experiences and perspectives to their municipality. As the participants became aware of these biases (for which they were in no way responsible), this clearly undermined their motivation and creativity. 
Thirdly, and most directly connected to ideas about the public, the community groups only considered it necessary to address local issues and perspectives. Unlike the community groups, the Citizens! and Voters refused to respect such categorisations of reality and moved with competence from local to global, and from practical to existential. What makes this comparison important is that the issues that concerned the participants in the community groups were not by definition local, quite the contrary. As noted above, the problems with mental health care in Siilinjärvi were essentially due to government policy. Some participants in the group and particularly the local authorities argued that the discussion was unnecessary and irrelevant because the local municipality is neither responsible for the policy, nor can it be changed through local action. Curiously enough, similar questions about mental health care have been raised in other parts of the country as well, but it remains unclear whether the problem should be addressed at the national level, where the decisions were made, or at the local level, where the problems are faced. It seems obvious that either level alone is inadequate.

In sum, these examples provide a vivid illustration of how the rationality created in the discussions served as a resource for the newsroom. This resource was developed by the reporters, but it could have been put into practice far more effectively. The project team had no problems composing a list of more than 60 suggestions for spin-off stories after the Citizens! discussions. These suggestions were roughly divided into three categories: (i) participants' direct questions to authorities, institutions, or other stakeholders; (ii) reports on the scene: listening to people afflicted by the problems concerned; and (iii) inquiries into the causes of the problems.

Only few items on the list were utilised, which was a disappointment to reporters and participants alike. Due to this disappointment reporters did not bother to compose similar lists about the community projects and the Voters, which meant that resource was utilised even more poorly. Later, the journalists have recognised, however, that the rationality of the groups has not expired. Most of these assignments would be still relevant, and some of them have been tackled more than one year after the discussions.

\section{Critical Voices}

The third feature in Carey's hopeful, albeit not perhaps historically adequate description of the public, is its criticalness. The critical competence of our groups was probably made apparent in the previous chapters that dealt with vested interests and rationality. However, criticism had a different role to play in each group. Its outcomes also differed to some extent.

For some groups criticism served as the foundation on the basis of which they gradually began to see their stakes and develop definitions for their problems and to contrive solutions. For others, the critique was the outcome of lengthy deliberation. Two extreme groups on this dimension were the community group in Suonenjoki and the young adults of Citizens! project. In spite of taking different routes, both groups arrived at quite similar results.

In Suonenjoki it was not difficult for the group to conclude that their municipality was in the middle of an economic and spiritual crisis. The immediate context for this crisis was the severe economic recession that swept across Finland in the 1990s, but beyond these general circumstances the group also detected local incompetence and apathy. As noted above, the group did not, however, want to go on lamenting their fate. Instead, they preferred to envision a better future based on active local participation. While the deliberation strengthened the argument in the group, it also developed their 
critical abilities. To put it metaphorically, the group vaccinated itself against the most obvious counterarguments that would attempt to dismiss their initiatives.

When the group met the newly appointed mayor, the participants suggested that the local administration should set up discussion groups to assist decision-makers and civil servants in their work. The mayor and a civil servant responsible of town planning both accepted the idea, but they maintained that citizens' juries should not be allowed to upset local democratic practices. The group responded by asking whether it really is viable to assume that residents' discussions could undermine representative democracy; surely that is an untenable position?

This question manages to be critical and constructive at the same time in its own right. Still, it is hardly a satisfactory response to the local authorities' concerns about the rules of democracy. It seem plausible that without such rules the discussion groups may have either too little or too much power respective to representative institutions. The problem may be solved simply by making the groups' work public. On the one hand, this would give the groups the opportunity to achieve power they need in order to have any influence at all. On the other hand, by submitting their contributions to public scrutiny and evaluation would make the groups accountable. This point is all the more significant, because new participatory practices for local planning - such as Environmental Impact Assessment (EIA) and Local Agenda 21 in Finland - pay no particular attention to the publicness of these practices (Heikkilä \& Kunelius 2000).

For young adults, criticism was not a point of departure but rather an end-point. In the same vein as in the case of ugly department stores, the issue of high housing costs became framed as a question of power. One quite successful event during the project took place some three months after the discussions, when the newsroom took an assignment from the group and investigated the explanations for high housing costs. The authorities explained in the leading story that there was quite simply a shortage of apartments, which in turn was due to the recession in the building industry in the mid-1990s. Even though the industry had pulled through the worst and was now picking up, construction firms were not yet able to produce new flats fast enough, the experts claimed.

One participant, who was allowed to comment on this response, said that while the argument makes sense, the experts were curiously silent about how the markets work. Building contractors are, of course, in the business to make profit. Therefore, he continued, the key question is not how many apartments there are, but whom they are built for. Who are the building industry's most favoured clients? The following quote included in the story pushes this critique forward rather succinctly:

I can see cranes out in the dock area, but hardly anywhere else. It's a nice spot out there with a beautiful view, so these apartments are going to be really expensive.

(Savon Sanomat, February 16, 1999).

These two examples illustrate how the discussion groups concluded their work with challenging questions - often phrased as 'how come?' - that should demand immediate responses. Clearly, not all arguments made by laypeople are correct, but this does not mean that their criticism and sometimes unorthodox questions are not publicly relevant. Their exposure to public scrutiny is not merely a way of holding actors in the public and private sector accountable for their deeds, but also a good way of rectifying misconceptions that ordinary citizens and institutions both have. This differs radically from common news practices according to which a reporter is expected to eliminate misconceptions and errors before a piece of news is even printed. It is not unreasonable to argue that this practice erases not only errors, but also important and critical arguments. 
Therefore, journalists might do better by submitting the evaluation of their relevance and 'factuality' to public scrutiny. ${ }^{10}$

The groups were not merely critical towards politicians and those in power. They also addressed questions about news journalism and the projects they had attended. While in most cases the participants were pleased with the projects and the stories covering their discussions, they also questioned whether the paper would be able to maintain this approach. The fact that spin-off stories remained rare and that even in those that were published the participants could not always find their arguments, raised doubts as to whether the experiments were completely sincere. For some of them, the projects proved to be just projects rather than something that could make a lasting difference in newswork. In Siilinjärvi some participants went even further in their criticism. Those who did not see the relevance of discussing the mental care situation felt that the discussion was motivated more by the researcher than by the participants.

The criticism towards the paper and the project team is indeed a healthy sign because in a way it proves that the participants have vested interests in news journalism. Even if the experiments did not lead to major changes, they did at least make themselves and the performance of the paper more accountable to the participants. Most participants said they assessed the paper and how news journalism works more carefully than they used to before. Now it matters to them who has written the story, who have been interviewed, and what questions have been asked. Here interest equals criticism.

Having said that, it has to be added that even if the project managed to enhance the participants' critical competencies with respect to journalism, this is hardly enough. The emergence of publics remained rather superficial in all three aspects: few stakeholders chose to stand up in public, stories were inadequately transformed into public processes (even though some promising signs seem to be emerging), and the budding criticism failed to bring about any major upheavals either in the newsroom or among the readers. On the other hand, the objective was not to change everything, but rather to gain experience from which new questions and initiatives might spring. That much was certainly achieved.

\section{Discussion}

Experimental research is more concerned with the assumptions underlying our routines than with 'reality in itself'. In this vein the projects analysed above serve as an hypothesis which clearly questions some taken-for-granted truths about citizens' capacities and motivation to act publicly.

In contrast to what vulgar elite theorists would assume, the 46 participants in our discussion groups appeared to be quite happy to participate in public affairs when they were given the opportunity to do so. A discussion - or rather a series of deliberative sessions - seemed like an appropriate method for developing their participatory motivation into relevant arguments, questions, and insights. The participants were also quite competent to evaluate critically and constructively issues in which they had previously shown a vested interest. This would seem to convince that citizens respective to news journalism are qualified for more than merely being silent observers and loyal subscribers. Even if these conclusions only cover the experiences of the participants, and not the readership in general, the outcome is significant an encouraging both conceptually and practically.

Conceptually, the experiments underscore the need to distinguish the public from the audience. They also give some clues as to what the public might mean empirically and 
contribute to further discussion on how it differs from other conceptions of the public, such as those advocated by cultural audience studies, or the discourses of communication policies. In addition, the analysis shows that Carey's description of the public has not only historical or nostalgic value, but it may provide inspiration for conceiving journalistic practices that attempt to address readers and viewers as citizens with vested interests rather than mute observers, self-absorbing consumers, or uninterested masses.

The big question that relates the projects to two configurations of journalism described in the beginning has to do with vested interests and their place in news journalism. According to ideas of thin journalism the news should be safeguarded from vested interests, particularly from those who appear to be unrepresentative. This idea seems to restrict or even preclude news journalism for taking advantage of citizens' public potentials. From the idea of strong journalism the argument could be quite the opposite: vested interests could safeguard the relevance of news journalism in the eyes of publics whoever and wherever they might be and even in those of self-critical journalists. These formulations, I think, refer quite aptly to two fundamental assumptions about news journalism and its democratic performance. It is not clear, what the consequences would be like, if we systematically chose one instead of the other. It is likely, though, that the practical consequences would be different from each other.

If journalists were to take the ideas of strong journalism and the experiences of the projects presented here seriously, the question that follows is: How is news journalism supposed to take advantage of citizens' competencies, and are journalists actually comfortable doing this? Surely, taking citizens and their vested interests seriously and create public occasions for their deliberations entails risks. One of them is to admit the shortcomings of newswork. At least our projects proved that the contributions of discussion groups were a hard nut to crack with the tools available. The story formats did not work satisfactorily, the team was unable to produce enough spin-off stories, and engaging public processes remained virtually non-existent.

All this suggests that a reorientation of journalistic practices should not be confused with religious experiences, as is often suggested by critics of public journalism (see Shepard 1994). Instead, a strengthening of the citizens-orientation requires several things at the same time. It is not enough simply to organise citizens' discussion groups and see what journalists can make of them. It is not enough to write engaging stories about citizens' concerns, unless the newsroom is not prepared for maintaining its interest and capable of developing the public discussion. Finally, it is not enough for one or two journalists to commit themselves to this sort of work, if the rest of the newsroom does its best to ignore - or worse - to debilitate these efforts.

At Savon Sanomat the conclusion drawn upon completion of the projects was (self-) critical. For journalists, the projects appeared to be too technical and too difficult to cope with. The reporters pointed out that the resources made available were too limited for such a pioneering effort. This interpretation was not, however, their final word. Thanks to the insistence of one reporter involved in the projects, the paper is currently experimenting again. During its first months, the news section for local coverage has shown some early and moderate signs of progress both in terms of the quality of stories and in terms of their consequences outside the paper. However, the steps are still very small, and there are no firm indications of any profound forthcoming changes in the newsroom.

Nonetheless the projects and their relative successes have cultivated a favourable spirit for further experiments. It is against this spirit to say anything conclusive about 
what these experiments will bring about. The best way to dismiss new ideas is to jump conclusions and escape reflection. The fact that journalists at their daily work are often compelled to do so make these experiments and their analysis even more challenging and important.

\section{Notes}

1. This observation is based on Veikko Pietilä's (2000) unpublished survey on contemporary audience studies. The analysis is based on a corpus mostly of cultural audience studies published between 1985 and 1999.

2. The Finnish journal for media studies Tiedotustutkimus (3/1999) has published a special issue on the concept of 'the public', including a Finnish translation of Herbert Blumer's classic article: The Crowd, The Mass, and the Public.

3. Carey's reading of history differs radically from Schudson's (1998) analysis of the same period. While Carey claims to be writing 'more useable history', Schudson quite explicitly wants to question nostalgic interpretations as obvious misconceptions of history (see also Schudson 1997a).

4. As political scientists are inclined to do, Barber does not even mention news journalism. Anderson et al. $(1996,161)$ would take this as evidence of how democracy theorists have bought the image that journalists have been selling. That image portrays journalists as conduits of information who do their job well when they are politically invisible.

5. For descriptions of public journalism projects in the US, see Charity 1995; Schaffer \& Miller 1995; Ford \& Schaffer 1998. The impact of these projects has been assessed by Lambeth et al. 1998 and Thorson et al. 1997.

6. The interviews expose three discourses on journalism (Heikkilä 1998). The paternalistic discourse emphasises the values of independent reporting and pays no particular attention to recipients either as audience or as public. The market voluntarist discourse denies the right of paternalists to judge what is best for the readers and endorses news that cater for the audience with the richest possible sortiment of 'truths', perspectives, and lifestyles. The critical discourse pushes journalism towards a better understanding of everyday life, but it is unable to showing how it could be done. Two former discourses resemble BechKarlsen's (1995) dichotomy enlightenment journalism vs. service journalism, whereas the critical discourse is absent in Bech-Karlsen.

7. An illuminating, albeit exceptional example is the Springfield News-Leader (Missouri), where the entire newsroom was assigned to detect forms of juvenile crime committed in the afternoons. The idea that at first sounded hazardous to reporters was later interpreted as successful (see Ford \& Schaffer 1998, 4-15).

8. All participants were asked to evaluate their experiences by responding to an open questionnaire. Thirty-six out of 46 participants returned the questionnaire.

9. These are almost the exact words with which Arendt (1990, 127 [1963]) describes "public happiness". These views contradict Schudson's $(1997 \mathrm{~b}, 304)$ argument that only sociable conversations can be enjoyable, but 'serious democratic discussions' are deeply uncomfortable.

10. This argument is developed further by Renvall \& Reunanen (1999). They ask whether news practices should not be aimed at representing ready-made truths, but become more adjusted to the idea that the news should contribute to a communal hunt of truth.

\section{References}

Anderson, Rob \& Dardenne, Robert \& Killenberg, George (1996) The American Newspaper as the Public Conversational Commons. Journal of Mass Media Ethics 11(1994): 3, pp. 159-165.

Arendt, Hannah (1990 [1963]) On Revolution. London: Penguin Books.

Barber, Benjamin (1984) Strong Democracy. Participatory Politics for the New Era. Berkeley: University of California Press.

Bech-Karlsen, Jo (1995) Det journalistiske selvbedrag. [The Journalistic Self-Betrayal]. Norsk Medietidsskrift (1995):1, pp. 5-27.

Borg, Sami (1997) Puolueet ja edustuksellinen demokratia [The Political Parties and the Representative Democracy]. University of Tampere: Department of Local Government Studies.

Carey, James (1987) The Press and Public Discourse. The Center Magazine 20(1987):2, pp. 4-16.

Carey, James (1997) Afterword: The Culture in Question. In: Munson, Eve \& Munson, Catherine (eds.) James Carey. A Critical Reader. Minneapolis: University of Minnesota Press, pp. 308-339. 
Charity, Arthur (1995) Doing Public Journalism. New York: The Guildford Press.

Dahlgren, Peter (1995) Television and the Public Sphere. Citizenship, Democracy and the Media. London: Sage.

Dewey, John (1991 [1927]) The Public and its Problems. Athens (Fla): Swallow Press/Ohio University Press.

Ekecrantz, Jan \& Olsson, Tom (1990) Mellan makt och marknad. En studie av nyhetsjournalistiken [Between Power and the Market. A Study on News Journalism]. Stockholm: Maktutredningen.

Ford, Pat \& Schaffer, Jan (1998) Don't Stop There! Five Adventures in Civic Journalism. Washington D.C. \& San Francisco: Pew Center for Civic Journalism.

Friedland, Lewis \& Sotirovic, Mira \& Daily, Katie (1998) Public Journalism and Social Capital. The Case of Madison, Wisconsin. In: Lambeth Edmund \& Meyer, Philip \& Thorson, Esther (eds.) Assessing Public Journalism. Columbia (Mo): The University of Missouri Press, pp. 191-220.

Gans, Herbert (1980) ) Deciding What's News: A Study of CBS Evening News, NBC Nightly News, Newsweek and Time. London: Constable.

Glasser, Theodore (ed.) (1999) The Idea of Public Journalism. New York: The Guildford Press.

Glasser, Theodore \& Craft, Melanie 1996) Public Journalism and the Prospects for Press Accountability. Journal of Mass Media Ethics 11(1994): 3, pp. 152-158.

Harwood Group (1993) Meaningful Chaos. How People Form Relationships with Public Concerns. Dayton (Oh): Kettering Foundation.

Heikkilä Heikki (1998) Journalismin tonttia mittailemassa. [Journalists Measuring Journalism] Tiedotustutkimus 21(1998):2, pp. 76-91.

Heikkilä Heikki \& Kunelius, Risto (2000) Julkisuuskoe. Kansalaiskeskustelun opetuksia koneistoille. [A Public Experiment: Lessons of Civic Discussion for Institutions]. Helsinki: Kunnallisalan kehittämissäätiö.

Huxman, Susan \& Iorio, Sharon (1996) Media Coverage of Political Issues and the Framing of Personal Contexts. Journal of Communication. 46(1996):4, pp. 97-115.

Jensen, Klaus Bruhn (1990) Politics of Polysemy: Television News, Everyday Consciousness and Political Action. Media \& Culture \& Society 12(1990):4, pp. 57-77.

Kunelius, Risto (1999a) Journalismi keskustelun tiellä. [Journalism on the Way of Conversation]. Tiedotustutkimus 22(1999):3, pp. 42-59.

Kunelius, Risto (1999b) Uutisista keskusteluun ja takaisin. [From the News to Conversation and Back]. Tampere: University of Tampere, Journalism Research and Development Centre.

Lambeth Edmund \& Meyer, Philip \& Thorson, Esther (1998) (eds.) Assessing Public Journalism. Columbia (Mo): The University of Missouri Press.

McManus, John (1994) Market Driven Journalism. Let the Citizens Beware? Thousand Oaks (Ca): Sage.

Merritt, Davis Jr. (1995) Public Journalism and Public Life. Why Telling the News Is Not Enough. Hillsdale (NJ): Lawrence Erlbaum.

Murdock, Graham (1992) Citizens, Consumers, and Public Culture. In: Skovmand, Michael \& Schröder, KimChristian (eds.) Media Cultures: Repappraising Transnational Media. London: Routledge, pp. 17-41.

Pekola-Sjöblom, Marianne (1997) Kuntalaisten vieraantuneisuus kunnallisesta päätöksenteosta. [Muncipal inhabitants' estrangement from municipal decision-making]. In: Mäki-Lohiluoma, Kari-Pekka \& PekolaSjöblom, Marianne \& Ståhlberg, Kristian (eds.) Kuntalaisten valta ja valinnat. [Power and choices of inhabitants of municipalities]. Helsinki: Suomen Kuntaliitto, pp. 133-157.

Pietilä, Veikko (1999) Julkiso ja yleisö [The Public and the Audience]. Tiedotustutkimus 22(1999):3, pp. 4-13.

Pietilä, Veikko (2000) 'The Public' as a Construct in the Discourse on Audience. (unpublished manuscript).

Pietilä, Veikko \& Ridell, Seija (1997) Julkea ehdotus. [A Public Proposal] Tiedotustutkimus 21(1998):1, p. 95.

Renvall, Mika \& Reunanen, Esa (1999) Yleisö totuutta etsimässä. [Community in the Hunt for Truth]. Tiedotustutkimus 22(1999):3, pp. 76-91.

Ridell, Seija (1998) Tolkullistamisen politiikkaa. [The Politics of Sense Making: The Reception of TV-News from a Critical Genre Perspective]. Acta Universitatis Tamperensis 617.

Ridell, Seija (1999) Tutkimus julkisoa tuottamassa. [Provoking and Promoting the Public]. Tiedotustutkimus 22(1999):3, pp. 28-41.

Rifkin, Jeremy (1995) The End of Work: The Decline of the Global Labor Force and the Dawn of the PostMarket Era. New York: Putnam's Sons.

Rosen, Jay (1996) Getting The Connections Right. Public Journalism and the Troubles of The Press. New York: 20th Century Foundation.

Rosen, Jay (1999) What Are Journalists for? New Haven: Yale University Press.

Sandel, Michael (1998) Liberalism and the Limists of Justice. Second Edition. New York: The Cambridge University Press. 
Schaffer, Jan \& Miller, Edward (eds.) (1995) Civic Journalism: Six Case Studies. Washington DC: The Pew Center for Journalism.

Schröder, Kim-Christian (1999) The Best of Both Worlds? Media Audience Research between Rival Paradigms. In: Alasuutari, Pertti (ed.) Rethinking the Media Audience. London: Sage, pp, 38-68.

Schudson, Michael (1997a) Toward a Troubleshooting Manual for Journalism History. Journalism \& Mass Communication Quarterly 74(1997):3, pp. 463-476.

Schudson, Michael (1997b) Why Conversation is Not the Soul of Democracy. Critical Studies in Mass Communication 14(1997), pp. 297-309.

Schudson, Michael (1998) The Good Citizen. New York: The Free Press.

Shepard, Alicia (1994) The Gospel of Public Journalism. American Journalism Review, September, pp. 28-34.

Thorson, Esther \& Friedland, Lewis \& Anderson, Peggy (1996) Civic Lessons. Report on Four Civic Journalism Projects Funded by The Pew Center for Civic Journalism. Philadelphia: The Pew Charitable Trusts. 